\title{
Sectoral Integration and Domestic Portfolio Diversification in the Karachi Stock Exchange
}

\author{
Awais Ahmed, ${ }^{*}$ Muhammad Nasir Malik, ${ }^{* *}$ Obaid Anwar \\ Awan, ${ }^{* * *}$ Asif Muzaffar ${ }^{* * * *}$
}

\begin{abstract}
This study analyzes sectoral integration among the top ten sectors listed on the Karachi Stock Exchange (KSE), using a market value-weighted index and daily stock price data for 2001-14. Since the literature shows that domestically diversified portfolios outperform globally diversified ones, the study's results have implications for the construction of well-diversified domestic portfolios among individual and institutional investors. We find that, apart from automobiles and cement, all other sectors listed on the KSE provide good diversification opportunities. The Granger causality test shows that cement, chemicals and banking cause most other sectors uni-directionally, while oil and gas, biotechnology and pharmaceuticals, textiles, and electricity are caused by most other sectors. From a domestic investor's perspective, the KSE provides reasonable diversification opportunities across different sectors.
\end{abstract}

Keywords: diversification, portfolio management, Karachi Stock Exchange, sectoral integration.

JEL classification: G110.

\section{Introduction}

Portfolio management is a widely discussed issue in the finance literature, given that selecting appropriate stocks in portfolio formation is a key investment decision. Prior to Markowitz's (1952) modern portfolio theory, which changed the dynamics of portfolio formation, investments were treated as standalone securities rather than constituents of a portfolio. Markowitz thus provided a new perspective of investment management by introducing the concept of correlation among returns on different securities. This allowed investors to look at systematic risk as the only

\footnotetext{
* Lecturer, Lahore Business School, University of Lahore.

** Assistant professor, Business School, University of Central Punjab, Lahore.

${ }^{* * * *}$ Lecturer, RMIT University, Australia.

***** Assistant professor, University of Central Punjab, Lahore.
} 
priced risk in the context of a well-diversified portfolio, whereby some of the unsystematic risk could be diversified away through the inclusion of uncorrelated securities.

Subsequently, as Grubel and Fadner (1971) show, diversification opportunities became increasingly available in global capital markets. Rational investors began to diversify their investment portfolios, initially at the domestic level, and then leveraging the concept to create globally diversified portfolios. Globalization, the emergence of multinational companies and electronic stock trading have since reduced the barriers to international investment. There has been a marked increase in cross-border investment in capital markets. At the same time, international stock markets have become more integrated, causing diversification opportunities to shrink.

Wong et al. (2004) note that integration among the stock markets of different countries increased after the market crash of 1987. Ahmed (2012) argues that this integration has increased further since the Asian financial crisis of 1997. The impact of $9 / 11$ and the global financial crisis of 2008 on capital markets across developed and emerging economies alike indicates that cross-border portfolio diversification is not necessarily as effective as perceived. On the other hand, despite the widespread acceptance of modern portfolio theory, under-diversification is still prevalent among investors. Blume, Crockett and Friend (1974) examine a sample of individual investor portfolios and find them to be significantly underdiversified. Some 30 years later, Goetzmann and Kumar (2008) report similar results. A behavioral explanation provided in the literature pertains to narrow framing bias, whereby investors perceive securities' returns to be positively correlated and thus underestimate the benefits of diversification.

In the context of Pakistan, many studies have measured the integration of the Karachi Stock Exchange (KSE) with other stock markets in developed and emerging economies, following the trend of international diversification. However, as opportunities for international diversification diminish on the heels of greater global market integration, investors have begun to refocus on domestic portfolio diversification.

The literature provides very little information on the integration or lack thereof - of returns in different sectors listed on the KSE. Accordingly, we attempt to address this gap by examining the degree of correlation and integration among sectors of the KSE. The results could prove useful for institutional as well as individual investors in portfolio 


\section{Exchange}

formation by identifying which sectors provide the most diversification benefits. Although the study has a domestic focus, it may be of equal interest to regional investors, given that the KSE has emerged as an important regional stock exchange in the last few years. In 2014, Bloomberg ranked the KSE as the world's third-best performing stock market since 2009, while the MSCI has recently listed the KSE in its emerging markets index.

\section{Literature Review}

Portfolio construction is the science of choosing an appropriate combination of securities from the investment universe. Following the introduction of modern portfolio theory, numerous studies have examined aspects of portfolio management. Evans and Archer (1968) find that the variance of a portfolio is inversely related to the number of securities it contains: the greater the number of securities, the fewer chances that their prices will fall simultaneously. Booth and Fama (1992) show that a portfolio's compounded return is higher than the weighted average of the compounded returns of all the assets in that portfolio. This is because the contribution of each asset to the portfolio return is greater than its compounded return. Sankaran and Patil (1999) demonstrate that the benefits of holding many securities are greater than holding a single security.

As another strand of the literature shows, despite the wide acceptance of modern portfolio theory, many investors remain underdiversified. Blume et al. (1974) analyze a sample of investment portfolios to assess the extent of under-diversification and find that 34 percent of investors held only one stock, 55 percent held between one and ten stocks, and only 11 percent held more than ten stocks in their portfolios. Goetzmann and Kumar (2008) examine a sample of 40,000 investors from 1991 to 1996 and observe that most of them are under-diversified and seem to give little importance to correlation among stocks. Barberis, Huang and Thaler (2006) argue that, historically, most people are reluctant to allocate their money in stock markets even though the stock market has a high mean return and low correlation compared to other household risks.

With the onset of globalization and concomitant changes in financial technology and innovation, the 1970s saw a rising trend in crossborder diversification. Levy and Marshall (1970) argue that a key reason investors opt for cross-border investment is to avoid country-specific risk. The World Bank (1997) notes that the world's financial markets have become global marketplaces, with investors diversifying their portfolios 
among various developing countries to achieve higher returns and minimize their risk. Bodie, Kane and Marcus (1999) emphasize the benefits of international diversification by arguing that an internationally diversified portfolio bears less risk than one diversified solely in the US.

Following this recognition of the importance of international diversification, numerous studies have attempted to measure the integration of developed, emerging and regional markets. Most of these studies focus on equity markets in developed countries or regions, including the US, Europe and Japan. The emergence of Asian capital markets in the 1990s, however, has prompted greater research on the degree of integration between these markets and other stock markets in developed countries.

In the context of the KSE, numerous studies have been conducted that measure its integration with other global markets. Husain and Saidi (2000) examine the integration of the Pakistani stock market with those of the US, France, the UK, Germany, Japan, Hong Kong and Singapore. Using cointegration analysis, they find that the former is not integrated with international markets.

Arshad, Saleem and Abdullah (2008) measure the integration between the KSE and a sample of developed country stock markets (the US, the UK, Italy, Germany, Canada, France, Japan and Australia). They find that the KSE is integrated only with the French and Japanese stock markets. Iqbal, Khalid and Rafiq (2011) explore the relationship between three stock markets - the US, Pakistan and India - and find no evidence of cointegration among them. However, their Granger causality test results show that the US stock market has a unidirectional influence over the KSE in Pakistan and the Bombay Stock Exchange in India.

Aamir, Husnain and Ali (2012) examine the relationship between the Pakistani stock market and the G8 country stock markets (the UK, the US, Canada, Japan, France, Germany, Italy and Russia). Applying the multivariate cointegration approach, they find no long-term relationship between the Pakistani stock market and G8 stock markets. However, the Granger causality test results reveal unidirectional causality between the Pakistani market and the stock markets of France, Japan, Germany, the UK and Italy.

Hussain et al. (2013) investigate the relationship among several South Asian stock markets - Pakistan, India, Bangladesh and Sri Lanka - as 


\section{Exchange}

well as between these markets and the US, UK, Australian and Japanese stock markets. While no significant relationship emerges, the study's Granger causality test results indicate bidirectional causality between the Colombo Stock Exchange and the KSE. Khan and Aslam (2014) assess the cointegration of the Pakistani stock market with a sample of Asian stock markets, including Japan, China, Singapore, Malaysia, India and Indonesia. Applying the Johansen-Juselius cointegration test, they find that the Pakistani stock market is integrated with the stock markets of India, Indonesia, Singapore and Malaysia.

With increased globalization, the flow of information from one country to another has become very fluid, such that shocks in one part of the world may also be felt elsewhere. International financial markets have also become more integrated. When investors invest in foreign markets, the transaction costs involved are likely to be higher than in domestic markets. Moreover, exchange rate fluctuations may increase the associated risk (Odier \& Solnik, 1993).

According to Longin and Solnik (1995), the correlation among stock markets rises in periods of high volatility. Errunza, Hogan and Hung (1999) argue that the benefits of diversifying a portfolio cross-border are statistically and economically insignificant compared to diversifying a portfolio of domestic assets. The incremental gains from international portfolio diversification over domestic portfolio diversification have also diminished over time as investment barriers change. Cavaglia, Melas and Tsouderos (2000) show that the reward-to-risk ratios of portfolios diversified across industries are better than those for portfolios diversified across countries.

Increased investment in international markets has also meant a decline in the benefits of diversification due to greater integration. Examining the degree of integration among major stock markets prior to, and after, the wave of globalization that occurred in the 1980s, Masih and Masih (2002) find that these markets became more integrated postglobalization. Schwebach, Olienyk and Zumwalt (2002) observe that the benefits of international diversification have declined significantly after the Asian crisis of 1997. Mun (2005) notes that the cross-market contagion effect of 9/11 has created an adverse investment environment for internationally diversified investors, with the impact reaching stock markets in the UK, Germany and Japan. Ahmed (2012) argues that the viability of cross-border portfolio diversification has fallen heavily since the 
1987 Wall Street crash, the Asian financial crisis of 1997, 9/11 and the subprime mortgage crisis of 2008.

Following the increased integration and reduced diversification opportunities across global financial markets, investors and academics have turned their attention to the diversification opportunities available domestically. Arbelaez, Urrutia and Abbas (2001) measure the level of integration among six key sectors of the Colombian stock market. Testing for stationarity, cointegration, causality, impulse response and variance decomposition in a vector error correction model, they find that the selected indices exhibit long-term linkages. In half these cases, the indices indicate Granger causality in the short term.

Gee and Karim (2005) measure the degree of integration among five sectors of the Kuala Lumpur Stock Exchange Composite Index in Malaysia. They apply unit root tests, multivariate cointegration and causality tests to a vector autoregression (VAR) model and vector error correction model, using daily and weekly closing price data over three periods (pre-crisis, crisis and post-crisis). The results show short-term causality between these sectors. The construction sector is found to have led other price indices before the crisis, while the financial sector played the most significant role in influencing prices post-crisis.

Wang, Kutan and Yang (2005) explore the relationship among major sector indices in the Shanghai and Shenzhen stock exchanges for the period 1993-2001. Their results indicate a high degree of interdependence, implying that the benefits of diversification among these sectors is relatively limited. Constantinou et al. (2008) use daily price index data for 12 sectors listed on the Cyprus Stock Exchange from 1996 to 2002, but find no evidence of cointegration. Al-Fayoumi, Khamees and Al-Thuneibat (2009) investigate the degree of sectoral integration in the Amman Stock Exchange in Jordan and observe that, barring services, the other sectors are integrated with each other, indicating opportunities for diversification for investors.

Ahmed (2012) examines the short-run and long-run relationship among 12 sectors of the Egyptian stock market, using daily sector indices data for 2007-10. Applying multivariate cointegration and Granger causality tests, he finds that the stock market offers the benefits of diversification in the short run, whereas the benefits of diversifying portfolios among these sectors in the long run are more limited. Noor, Khan and Khan (2014) investigate the integration among ten sectors of the 


\section{Exchange}

Bombay Stock Exchange, using daily sector indices data for 2010-13. They apply Johansen's cointegration and Granger causality tests and find that the banking and IT sectors are integrated and that consumer durables and realty are integrated. The other sectors provide an excellent opportunity for domestic investors to diversify their portfolios.

What this review of the literature reveals is that, while several studies have measured the degree of integration between the KSE and other stock markets in developed or emerging economies, there has been no comprehensive study of integration (or lack thereof) among the various sectors constituting the KSE. This study attempts to investigate the possible integration and causal relationships among various sectors of the KSE. Its findings are expected to help investors diversify their portfolios among different sectors to minimize portfolio risk.

\section{Data and Methodology}

The KSE currently has over 600 companies listed across 36 sectors. We select those sectors that represent more than 2 percent of the total market capitalization of the KSE to measure integration. Table 1 gives the selected sectors and their percentage share of total market capitalization. These sectors represent about 88 percent of the total capitalization of the KSE.

Table 1: Selected KSE sectors and market capitalization

\begin{tabular}{llc}
\hline & \multicolumn{1}{c}{ Sector } & Market capitalization \\
\hline 1 & Automobiles and parts & $3.35 \%$ \\
2 & Commercial banking & $19.71 \%$ \\
3 & Cement & $7.31 \%$ \\
4 & Chemicals & $10.32 \%$ \\
5 & Electricity & $4.39 \%$ \\
6 & Food producers & $10.84 \%$ \\
7 & Oil and gas & $20.67 \%$ \\
8 & Personal goods/textiles & $4.81 \%$ \\
9 & Pharma and biotech & $2.50 \%$ \\
10 & Tobacco & $4.10 \%$ \\
\hline
\end{tabular}

Source: Authors' calculations.

We select five companies from each sector, apart from tobacco, which includes only three companies (see the Appendix for a list of the companies selected in each sector). The selected firms represent the bulk 
of that sector's capitalization - on average, over 70 percent. The final sample represents 75 percent of the total market capitalization of the KSE. In the absence of sectoral indices, we develop daily market valueweighted indices of the selected sectors for the period 1 January 2001 to 31 December 2014.

Figure 1 reveals some interesting trends. The growth rate of different sectors from 2001 to 2005 is moderate and almost all sectors follow a similar trend. The banking sector experienced exponential growth from 2005 to 2008 until the global financial crisis. However, its recovery was phenomenal and the sectoral index shows the highest growth over the study period. In terms of growth, banking is followed by oil and gas, food production, cement and automobiles. Most sectors have experienced healthy growth since 2012, except for textiles, chemicals and electricity.

Figure 1: Sectoral market-weighted indices

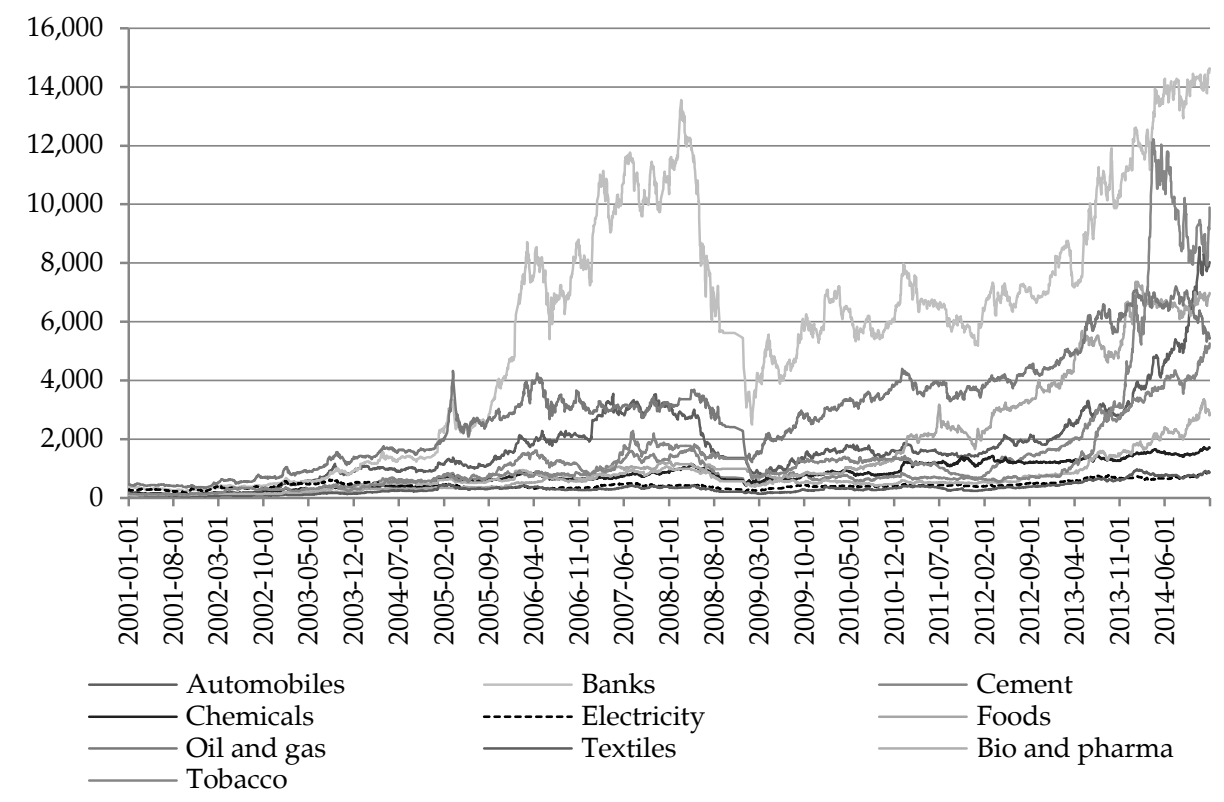

\section{Research Methodology}

We begin by examining the nature and strength of the relationship between the different sectoral indices, for which cross-sector correlations are estimated as follows: 


$$
\rho_{x y}=\frac{\sigma_{x y}}{\sigma_{x} \sigma_{y}}
$$

where $\sigma_{x y}$ represents the covariance between sectors $x$ and $y, \sigma_{x}$ and $\sigma_{y}$ are the standard deviations of the returns on sectors $x$ and $y$ and $\rho_{x y}$ is the correlation coefficient.

While correlation analysis measures the degree of co-movement between two series over a certain period, it is not sufficient to ascertain the presence of a long-run stationary relationship between the two. A cointegration analysis must be performed to determine whether an equilibrium relation exists. To illustrate this argument, consider a twovariable regression model: $Y_{t}=\beta_{1}+\beta_{2} X_{t}+u_{t}$. The classical ordinary least squares assumptions suggest:

$$
\beta_{2}=\frac{\sum\left(X_{t}-\bar{X}\right)\left(Y_{t}-\bar{Y}\right)}{\left(X_{t}-\bar{X}\right)^{2}}
$$

Let us suppose that $X_{t} \sim I(1)$, but $Y_{t} \sim I(0)$. In this case, $X_{t}$ is nonstationary but $Y_{t}$ is stationary at level. Even if $X_{t}$ and $Y_{t}$ demonstrate significant periodic correlation, a long-run relationship does not exist between the two variables. Since $X_{t}$ is nonstationary, its variance will increase over time, thus causing the estimator $\beta_{2}$ to converge to 0 as the sample size increases. The estimator $\beta_{2}$ does not have a nonlimiting or asymptotic distribution and is therefore no longer unbiased.

\subsubsection{Unit Root Test}

Before examining the cointegration between sectors, it is necessary to establish that each series is integrated of the same order (see Granger, 1981; Engle \& Granger, 1987). Two different tests are used to ascertain the order of integration. The first one, the Dickey-Fuller (DF) test, involves estimating the following equation:

$$
\Delta Y_{t}=\delta Y_{t-1}+u_{t}
$$

where $Y_{t}$ is the sector index for a given day, $Y_{t-1}$ represents the sector index for the previous day, $\delta$ is the correlation coefficient and $u_{t}$ is the error term. Since a critical limitation of the DF test is serial correlation, we also apply the Phillips-Perron test to account for heteroskedasticity and autocorrelation in the error terms, using the Newey-West heteroskedasticity and autocorrelation-consistent covariance matrix estimator. 


\subsubsection{Johansen's Multivariate Cointegration Test}

Two or more sectors are said to be integrated with each other if they show a tendency to move together. Johansen's multivariate cointegration test is used to test the long-run and short-run equilibrium relationship between the nonstationary indices of all the sectors:

$$
\lambda_{\text {trace }}=-T \sum \ln \left(1-\lambda_{i}\right)
$$

where $\lambda_{i}$ is the estimated eigenvalue and $\lambda_{\text {trace }}$ is the trace statistic.

\subsubsection{Granger Causality Test}

An important characteristic distinguishing cointegration from correlation is the presence of causal flow (Engle \& Granger, 1987). For a series to be cointegrated, there must be at least one causal flow in the integrated system. To ascertain potential cross-interactions among the sectors, we use the Granger causality test.

If two sectors are integrated, the integration may be either unidirectional or bi-directional. Unidirectional integration exists when changes in one sector occur independently of the other. Bidirectional integration, on the other hand, indicates that knowledge of the changes in one sector can improve the predictability of changes in the other and vice versa, that is, neither sector evolves independently of the other.

$$
Q_{\text {prob }}\left(W_{t+n} \mid \theta_{t}=Q_{p r o b}\left(W_{t+n} \mid \omega_{t}\right)\right.
$$

where $Q_{\text {prob }}$ is the conditional probability and $\omega_{t}$ the information set available at time $t$.

\section{Empirical Results}

This section presents the descriptive statistics and empirical results.

\subsection{Descriptive Statistics}

The summary statistics for all the market-weighted indices are presented in Table 2 . The automobile sector has the highest average daily return, followed by tobacco, showing that the daily changes in stock prices and/or volume are largest in these sectors. The lowest daily return is observed in the case of the chemicals sector with a mean return of 0.035 percent. The tobacco sector shows the greatest variability, with a standard 


\section{Exchange}

deviation of 2.61 percent. In contrast, the least volatility is observed in food production, which has a standard deviation of 1.39 percent. This suggests that the latter carries the least risk for investors.

Table 2: Descriptive statistics, market-weighted index returns

\begin{tabular}{lccccccc}
\hline Sector & Obs. & Mean & Min. & Max. & SD & Skewness & Kurtosis \\
\hline Automobiles & 3,353 & $0.1308 \%$ & $-19.3223 \%$ & $26.1869 \%$ & $1.8692 \%$ & 0.9676 & 22.7734 \\
Banking & 3,353 & $0.1086 \%$ & $-20.8907 \%$ & $22.3742 \%$ & $2.3117 \%$ & 0.5665 & 16.0659 \\
Cement & 3,353 & $0.1182 \%$ & $-14.8520 \%$ & $32.1465 \%$ & $2.1046 \%$ & 1.3891 & 22.9172 \\
Chemicals & 3,353 & $0.0354 \%$ & $-16.9831 \%$ & $22.9485 \%$ & $1.8251 \%$ & 0.4572 & 21.5118 \\
Electricity & 3,353 & $0.1013 \%$ & $-23.3015 \%$ & $22.6890 \%$ & $1.8523 \%$ & -0.3828 & 26.4822 \\
Foods & 3,353 & $0.1013 \%$ & $-43.5777 \%$ & $6.4166 \%$ & $1.3955 \%$ & -9.7829 & 294.7364 \\
Oil and gas & 3,353 & $0.0734 \%$ & $-18.2456 \%$ & $14.2412 \%$ & $1.9846 \%$ & -0.3997 & 10.2335 \\
Textiles & 3,353 & $0.0644 \%$ & $-16.0558 \%$ & $25.4899 \%$ & $1.9353 \%$ & 0.8227 & 17.9723 \\
Bio and pharma & 3,353 & $0.1002 \%$ & $-16.6326 \%$ & $35.5867 \%$ & $2.0832 \%$ & 2.1764 & 47.6784 \\
Tobacco & 3,353 & $0.1240 \%$ & $-13.4505 \%$ & $19.6419 \%$ & $2.6137 \%$ & 0.3803 & 6.2963 \\
\hline
\end{tabular}

Source: Authors' calculations.

We also examine the normality of the index returns. Obtaining information on the distribution of the underlying price series is important to investors as it indicates the possibility of sharp fluctuations in prices. Moreover, return dynamics such as volatility, skewness and kurtosis are often employed as inputs to models used in portfolio selection and optimization. Our results show that, apart from electricity, food production and oil and gas, the returns on all sectors are positively skewed, which points to the presence of extreme values at the positive end of the distribution. The kurtosis value for all sectors is greater than 3 , suggesting a leptokurtic distribution. This finding is unsurprising as stock returns often tend to be fat-tailed and positively skewed (Andersen et al., 2001).

\subsection{Correlation Results}

The results of the correlation matrix of market-weighted index returns in Table 3 show that the automobile sector is weakly correlated to food production and tobacco, and moderately correlated to the other sectors. Banking is strongly correlated to cement, chemicals and oil and gas, as these sectors have a high proportion of debt in their capital structure. Banking is weakly correlated to food production and tobacco, since most of the companies in these sectors are equity-financed. Cement is strongly correlated to chemicals, oil and gas, and textiles, and weakly correlated to food production and tobacco. 
Table 3: Correlation of market-weighted index returns

\begin{tabular}{|c|c|c|c|c|c|c|c|c|c|c|}
\hline Sector & 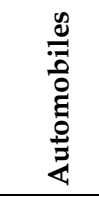 & 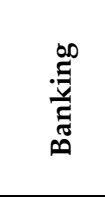 & Uี & & 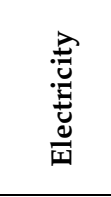 & 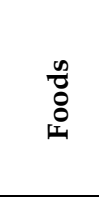 & 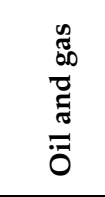 & 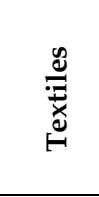 & 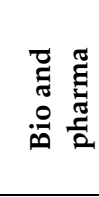 & 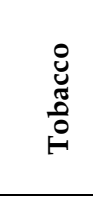 \\
\hline Automobiles & 1.0000 & & & & & & & & & \\
\hline Banking & 0.4479 & 1.0000 & & & & & & & & \\
\hline Cement & 0.4661 & 0.6187 & 1.0000 & & & & & & & \\
\hline Chemicals & 0.3904 & 0.6258 & 0.5855 & 1.0000 & & & & & & \\
\hline Electricity & 0.3225 & 0.4754 & 0.4791 & 0.5125 & 1.0000 & & & & & \\
\hline Foods & 0.0889 & 0.0960 & 0.1170 & 0.1258 & 0.0878 & 1.0000 & & & & \\
\hline Oil and gas & 0.3724 & 0.6175 & 0.5687 & 0.5891 & 0.5142 & 0.1116 & 1.0000 & & & \\
\hline Textiles & 0.4110 & 0.5786 & 0.5880 & 0.5459 & 0.4441 & 0.1142 & 0.5371 & 1.0000 & & \\
\hline $\begin{array}{l}\text { Bio and } \\
\text { pharma }\end{array}$ & 0.3379 & 0.4522 & 0.3705 & 0.4009 & 0.2303 & 0.0937 & 0.3333 & 0.3253 & 1.0000 & \\
\hline Tobacco & 0.1784 & 0.2383 & 0.2467 & 0.2143 & 0.1771 & 0.0687 & 0.2324 & 0.2237 & 0.1597 & 1.0000 \\
\hline
\end{tabular}

Source: Authors' calculations.

Chemicals and electricity are strongly correlated to oil and gas, since both sectors depend heavily on oil. Oil and gas and textiles are strongly correlated to banking, cement and chemicals, and weakly correlated to food production and tobacco. The biotech and pharma sector is moderately correlated to all other sectors. Food production and tobacco are the least correlated sectors in terms of daily returns with all other sectors. In general, food production and tobacco provide the best opportunity for portfolio diversification in a domestic context.

The correlation matrix indicates that the returns on different sector indices are positively related, but does not provide any information on the spread between the returns of two indices or whether the spread is meanreverting. In other words, the presence of positive correlation does not necessarily imply a long-run equilibrium between the returns on different indices. For a long-run equilibrium to exist, the spread or linear combination of two returns series must be stationary. To verify the presence of a long-run equilibrium, a cointegration procedure must be employed. Even if two nonstationary series are strongly and positively correlated, it may not be possible to draw valid inferences based on past behavior.

\subsection{Unit Root Tests}

One of the assumptions in running cointegration tests is that the underlying time series must be integrated of the same order. The DF and 
Phillips-Perron tests are used to examine the stationarity of the data. In both cases, their results are broadly consistent with the time series behavior of the variables indicated in Figure 1. Since the null of nonstationarity cannot be rejected at level in all cases, the reported variables are retested in first-difference form. Table 4 shows that the null hypothesis is rejected for all variables, thus clearly indicating that they are all integrated of order 1 or I(1).

Table 4: Stationarity test results

\begin{tabular}{lllllllll}
\hline Sector & \multicolumn{2}{c}{$\begin{array}{c}\text { ADF test (level } \\
\text { 0) }\end{array}$} & \multicolumn{2}{c}{$\begin{array}{c}\text { ADF test index } \\
\text { (level 1) }\end{array}$} & \multicolumn{2}{c}{$\begin{array}{c}\text { Phillips-Perron } \\
\text { test (level 0) }\end{array}$} & \multicolumn{2}{c}{$\begin{array}{c}\text { Phillips-Perron } \\
\text { test (level 1) }\end{array}$} \\
\cline { 2 - 9 } & T-stat & Prob. & T-stat & T-stat & T-stat & Prob. & T-stat & Prob. \\
\hline Automobiles & 4.806 & 1.0000 & -51.448 & $0.0000^{*}$ & 3.738 & 1.0000 & -51.835 & $0.0000^{*}$ \\
Banking & -0.016 & 0.9572 & -51.432 & $0.0000^{*}$ & -0.332 & 0.9208 & -51.762 & $0.0000^{*}$ \\
Cement & 5.165 & 1.0000 & -52.020 & $0.0000^{*}$ & 4.548 & 1.0000 & -52.248 & $0.0000^{*}$ \\
Chemicals & -0.144 & 0.9448 & -51.404 & $0.0000^{*}$ & -0.222 & 0.9358 & -51.182 & $0.0000^{*}$ \\
Electricity & 0.089 & 0.9653 & -54.861 & $0.0000^{*}$ & -0.061 & 0.9532 & -54.936 & $0.0000^{*}$ \\
Food prod. & 2.289 & 0.9989 & -54.792 & $0.0000^{*}$ & 1.910 & 0.9985 & -54.953 & $0.0000^{*}$ \\
Oil and gas & -0.936 & 0.7759 & -52.073 & $0.0000^{*}$ & -1.066 & 0.7286 & -52.599 & $0.0000^{*}$ \\
Textiles & 0.772 & 0.9912 & -51.590 & $0.0000^{*}$ & 0.344 & 0.9793 & -51.692 & $0.0000^{*}$ \\
Bio and & 2.877 & 1.0000 & -52.683 & $0.0000^{*}$ & 2.372 & 0.9990 & -52.692 & $0.0000^{*}$ \\
pharma & & & & & & & & \\
Tobacco & 3.063 & 1.0000 & -51.332 & $0.0000^{*}$ & 1.536 & 0.9977 & -51.552 & $0.0000^{*}$ \\
\hline
\end{tabular}

Note: The 1 percent critical value is -3.430 . ${ }^{*}$ indicates significance at 1 percent.

Source: Authors' calculations.

\subsection{Lag Length Selection}

To run cointegration and Granger causality tests, it is important to determine the lag length, based on which we gauge which sectors are integrated with each other and cause the movement of other sectors. The VAR lag length selection test is run to determine the appropriate lag lengths for establishing Granger causality. The test uses five methods, three of which - the likelihood ratio, final prediction error and Akaike information criterion - suggest a lag length of 4 (Table 5). 
Table 5: VAR lag length selection criteria

\begin{tabular}{lcccccccc}
\hline Lag & LL & \multicolumn{1}{c}{ LR } & df & P & FPE & AIC & HQIC & SBIC \\
\hline 0 & -239848 & & & & $7.30 \mathrm{E}+49$ & 143.199 & 143.205 & 143.217 \\
1 & -153404 & $1.70 \mathrm{E}+05$ & 100 & 0.000 & $3.00 \mathrm{E}+27$ & 91.650 & 91.722 & 91.851 \\
2 & -152964 & 879.94 & 100 & 0.000 & $2.50 \mathrm{E}+27$ & 91.447 & $91.584^{*}$ & $91.830^{*}$ \\
3 & -152829 & 270.14 & 100 & 0.000 & $2.40 \mathrm{E}+27$ & 91.426 & 91.628 & 91.992 \\
4 & -152664 & $328.73^{*}$ & 100 & 0.000 & $2.3 \mathrm{e}+27^{*}$ & $91.387^{*}$ & 91.655 & 92.136 \\
\hline
\end{tabular}

Note: * lag order selected based on criterion, $\mathrm{LR}=$ sequential modified likelihood ratio test statistic, $\mathrm{FPE}=$ final prediction error, $\mathrm{AIC}=$ Akaike information criterion, $\mathrm{SBIC}=$ Schwarz Bayesian information criterion.

Source: Authors' calculations.

\subsection{Multivariate Cointegration Test}

Interpreting the results of Johansen's multivariate cointegration test is based on either the eigenvalue or trace statistic - in this case, we use the latter. The trace statistic value of a selected index should be less than the critical value of the given rank. The rank represents the number of possible cointegrating equations. Table 6 gives the results of Johansen's multivariate cointegration test, according to which there are two cointegrating series among the ten selected sectors of the KSE.

Table 6: Multivariate cointegration test results

\begin{tabular}{cccc}
\hline \multirow{2}{*}{ Maximum rank } & \multicolumn{2}{c}{ Market-weighted index } & \multirow{2}{*}{ 5\% critical value } \\
\cline { 2 - 3 } & Eigenvalue & Trace statistic & \\
\hline 0 & - & 345.1372 & 233.13 \\
1 & 0.03544 & 224.1909 & 192.89 \\
2 & 0.02034 & $155.3052^{*}$ & 156.00 \\
3 & 0.01422 & 107.3078 & 124.24 \\
4 & 0.00910 & 76.6729 & 94.15 \\
5 & 0.00723 & 52.3585 & 68.52 \\
6 & 0.00595 & 32.3602 & 47.21 \\
7 & 0.00463 & 16.7973 & 29.68 \\
8 & 0.00370 & 4.3725 & 15.41 \\
9 & 0.00127 & 0.1051 & 3.76 \\
10 & 0.00003 & & \\
\hline
\end{tabular}

Note: ${ }^{*}=$ null hypothesis rejected at 0.05 .

Source: Authors' calculations. 


\section{Exchange}

Since these test results only give the number of cointegrating equations or sectors, and not which sectors are integrated, we also run pairwise cointegration tests for each sector against the other selected sectors.

\subsection{Pair-Wise Cointegration Test}

Table 7 gives the results of the pair-wise cointegration of each sector with all other sectors. The decision is made based on the trace statistics with a 5 percent critical value of 15.41 . A value of less than 15.41 shows that there is no cointegration between the selected sectors. The results of the market-weighted index show that the automobile and cement sectors are cointegrated with all the other sectors. Banking, chemicals, textiles, and oil and gas are the least integrated sectors and are only integrated with automobiles and cement. Electricity, food production, biotech and pharma, and tobacco are integrated among themselves, but not with banking, chemicals, textiles or oil and gas.

Table 7: Pair-wise cointegration test results

\begin{tabular}{|c|c|c|c|c|c|c|c|c|c|c|}
\hline & 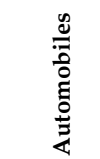 & 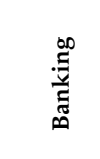 & छัّ & 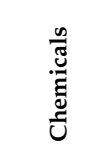 & 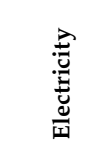 & $\begin{array}{l}\frac{n}{8} \\
8 \\
0\end{array}$ & 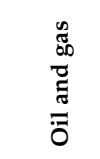 & 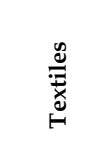 & 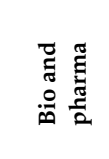 & 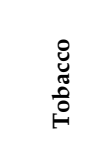 \\
\hline Automobiles & & 19.5142 & 34.2887 & 16.9816 & 23.8434 & 23.1667 & 25.7742 & 19.020 & 34.7492 & 30.6509 \\
\hline Banking & 19.5142 & & 25.7660 & $3.1743^{*}$ & $4.0539^{*}$ & $8.2328^{*}$ & $8.2025^{*}$ & $7.0796^{*}$ & $8.6644^{*}$ & $6.9035^{*}$ \\
\hline Cement & 34.2887 & 25.7660 & & 22.7339 & 29.8203 & 28.5747 & 32.1025 & 25.3622 & 48.8155 & 30.0357 \\
\hline Chemicals & 16.9816 & $3.1743^{*}$ & 22.7339 & & $4.5026^{*}$ & $9.8379 *$ & $7.4333^{*}$ & $4.8624^{*}$ & $7.3310^{*}$ & $7.2799^{*}$ \\
\hline Electricity & 23.8434 & $4.0539^{*}$ & 29.8203 & $4.5026^{*}$ & & $12.8795^{*}$ & $2.8085^{*}$ & $12.972^{*}$ & 16.9717 & 15.5924 \\
\hline Foods & 23.1667 & $8.2328^{*}$ & 28.5747 & $9.8379^{*}$ & $12.8795^{*}$ & & $9.3530^{*}$ & $13.128^{*}$ & 17.6449 & 21.2377 \\
\hline Oil and gas & 25.7742 & $8.2025^{*}$ & 32.1025 & $7.4333^{*}$ & $2.8085^{*}$ & $9.3530^{*}$ & & $5.2224^{*}$ & $13.2134^{*}$ & $12.2696^{*}$ \\
\hline Textiles & 19.0204 & $7.0796^{*}$ & 25.3622 & $4.8624^{*}$ & $12.9720^{*}$ & $13.1283^{*}$ & $5.2224^{*}$ & & $13.2474^{*}$ & 19.4589 \\
\hline $\begin{array}{l}\text { Bio and } \\
\text { pharma }\end{array}$ & 34.7492 & $8.6644^{*}$ & 48.8155 & $7.3310^{*}$ & 16.9717 & 17.6449 & $13.213^{*}$ & $13.247^{*}$ & & 23.6069 \\
\hline Tobacco & 30.6509 & $6.9035^{*}$ & 30.0357 & $7.2799^{*}$ & 15.5924 & 21.2377 & $12.269^{*}$ & 19.4589 & 23.6069 & \\
\hline
\end{tabular}

Note: 5 percent critical value $=15.41,{ }^{*}=$ null hypothesis rejected at 0.05 .

Source: Authors' calculations.

\subsection{Granger Causality Test}

Table 8 gives the results of the Granger causality test for each sector vis-à-vis all other sectors. The results show that the automobile sector is Granger-caused by cement, textiles, biotech and pharma, and tobacco. Banking is Granger-caused by tobacco alone, and cement is Grangercaused by food production, biotech and pharma, and tobacco. The chemicals sector is not caused by any sector, electricity is Granger-caused 
by automobiles alone, and food production is caused by cement, biotech and pharma, and tobacco.

Table 8: Granger causality test results

\begin{tabular}{|c|c|c|c|c|c|c|c|c|c|c|c|}
\hline & \multicolumn{11}{|c|}{ Equation sectors } \\
\hline & & 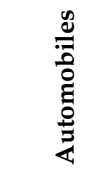 & 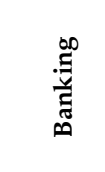 & $\begin{array}{l}\vec{\Xi} \\
\text { घँ } \\
\text { ü }\end{array}$ & 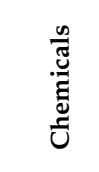 & 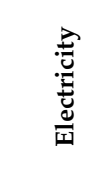 & $\begin{array}{l}n \\
0 \\
8 \\
0\end{array}$ & 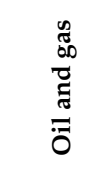 & 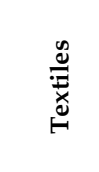 & 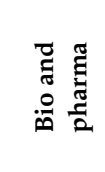 & 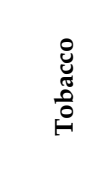 \\
\hline \multirow{10}{*}{ 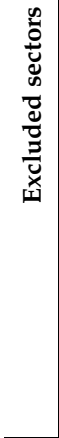 } & Automobiles & & 1.5211 & 5.127 & 3.2138 & $9.5969^{*}$ & 6.9309 & 4.955 & 3.5227 & $15.03^{*}$ & $25.774^{*}$ \\
\hline & Banking & 3.5245 & & 5.688 & 6.0431 & 6.0386 & 4.7326 & 4.7892 & 3.5277 & $9.4647^{*}$ & 1.7425 \\
\hline & Cement & $12.927^{*}$ & 0.74626 & & 4.9629 & 3.0861 & $12.429^{*}$ & $14.398^{*}$ & $18.988^{*}$ & $12.671^{*}$ & $30.517^{*}$ \\
\hline & Chemicals & 3.2037 & 8.0816 & 0.70621 & & 0.95656 & 1.9283 & 8.5665 & 7.3421 & $11.398^{*}$ & 7.2173 \\
\hline & Electricity & 6.6214 & 7.3939 & 8.2821 & 4.1024 & & 4.0843 & 9.2416 & 3.598 & 2.1466 & 4.3201 \\
\hline & Foods & 8.80037 & 1.9598 & $22.071^{*}$ & 8.5849 & 8.3192 & & 3.0223 & 3.194 & 3.2173 & $14.999^{*}$ \\
\hline & Oil and gas & 7.5267 & 2.2397 & 4.3606 & 0.40445 & 2.9971 & 5.94 & & 5.5597 & 5.4736 & 5.747 \\
\hline & Textiles & $10.639^{*}$ & 2.6917 & 7.0981 & 5.9469 & 9.1993 & 2.9024 & $14.125^{*}$ & & 8.4005 & $16.612^{*}$ \\
\hline & $\begin{array}{l}\text { Bio and } \\
\text { pharma }\end{array}$ & $10.628^{*}$ & 3.7644 & $36.44^{*}$ & 4.5255 & 8.0121 & $12.332^{*}$ & 7.6767 & $32.144^{*}$ & & 6.5487 \\
\hline & Tobacco & $38.55^{*}$ & $10.336^{*}$ & $54.903^{*}$ & 8.8881 & 2.9492 & $45.93^{*}$ & 2.7433 & $14.744^{*}$ & $24.317^{*}$ & \\
\hline
\end{tabular}

Note: * significant at 5 percent and excluded sector causes equation sector.

Source: Authors' calculations.

Oil and gas is Granger-caused by cement and textiles, and the latter is caused by cement, biotech and pharma, and tobacco. The biotech and pharma sector is Granger-caused by automobiles, banking, cement, chemicals and tobacco, whereas tobacco is caused by automobiles, cement, food production and textiles.

\section{Conclusion}

While the KSE has emerged as one of the world's top performing stock exchanges, small investors do not fare as well for lack of knowledge and their inability to diversify portfolios. The results of this study are thus especially helpful to investors who lack the resources to diversify their portfolios globally.

Studies conducted after the Asian financial crisis of 1997 and global financial crisis of 2008 show that the integration between global stock markets has increased, thereby reducing diversification opportunities. Recent trends 2000 onward suggest that investors are more inclined to seek diversification opportunities domestically. However, there is hardly any literature available on the KSE in this regard. Accordingly, this study aims 


\section{Exchange}

to help identify diversification opportunities domestically for institutional as well as individual investors.

We have identified those sectors of the KSE that provide good diversification opportunities domestically. The results of the correlation matrix show that the returns on automobiles, banking, chemicals, cement, electricity, oil and gas and textiles are moderately correlated to each other, whereas the returns on food production, biotech and pharma, and tobacco are less correlated, thus providing better diversification opportunities.

The results of the pair-wise Johansen cointegration test for selected sectors of the KSE, using a market-weighted index, show that most of these sectors are not integrated with each other in the long run, thus providing good diversification opportunities for portfolio managers and investors. The exceptions are the automobile and cement sectors, which are cointegrated with all the other sectors and do not provide opportunities for diversification. Biotech and pharma and tobacco are integrated only with electricity and food production. This implies that investors creating a portfolio of biotech and pharma and tobacco should adjust their allocations toward electricity or food production. Banking, chemicals, oil and gas, and textiles are the least integrated sectors and provide excellent diversification opportunities, especially for small and local investors who do not have access to foreign markets.

Finally, the results of the Granger causality test show that banking, chemicals and electricity are the least caused sectors, whereas automobiles, biotech and pharma, and tobacco are the most caused sectors. Chemicals, electricity, and oil and gas do not cause other sectors, whereas cement, biotech and pharma, and tobacco cause most of the other sectors. 


\section{References}

Aamir, S., Husnain, M., \& Ali, A. (2012). Is Pakistani equity market integrated to the equity markets of group of eight (G8) countries? An empirical analysis of Karachi Stock Exchange. Romanian Economic Journal, 15(45), 289-324.

Ahmed, W. M. (2012). Comovements and causality of sector price indices: Evidence from the Egyptian stock exchange. International Journal of Business and Emerging Markets, 4(3), 200-222.

Al-Fayoumi, N. A., Khamees, B. A., \& Al-Thuneibat, A. A. (2009). Information transmission among stock return indexes: Evidence from the Jordanian stock market. International Research Journal of Finance and Economics, 24, 194-208.

Andersen, T. G., Bollerslev, T., Diebold, F. X., \& Ebens, H. (2001). The distribution of realized stock return volatility. Journal of Financial Economics, 61(1), 43-76.

Arbelaez, H., Urrutia, J., \& Abbas, N. (2001). Short-term and long-term linkages among the Colombian capital market indexes. International Review of Financial Analysis, 10(3), 237-273.

Arshad, H., Saleem, H. M., \& Abdullah, M. S. (2008). Long-run relationships between an emerging equity market and equity markets of the developed world: An empirical analysis of Karachi Stock Exchange. International Research Journal of Finance and Economics, 16, 52-62.

Barberis, N., Huang, M., \& Thaler, R. H. (2006). Individual preferences, monetary gambles, and stock market participation: A case for narrow framing. American Economic Review, 96(4), 1069-1090.

Blume, M. E., Crockett, J., \& Friend, I. (1974). Stockownership in the United States: Characteristics and trends. Survey of Current Business, 54, 16-40.

Bodie, Z., Kane, A., \& Marcus, A. J. (1999). Investments (4th ed.). New York: McGraw-Hill.

Booth, D. G., \& Fama, E. F. (1992). Diversification returns and asset contributions. Financial Analysts Journal, 48(3), 26-32. 

Exchange

Cavaglia, S., Melas, D., \& Tsouderos, G. (2000). Cross-industry and crosscountry international equity diversification. Journal of Investing, $9(1), 65-71$.

Constantinou, E., Kazandjian, A., Kouretas, G., \& Tahmazian, V. (2008). Cointegration, causality and domestic portfolio diversification in the Cyprus stock exchange. Journal of Money, Investment and Banking, 4, 26-41.

Engle, R., \& Granger, C. (1987). Co-integration and error correction: Representation, estimation, and testing. Econometrica, 55(2), 251-276.

Errunza, V., Hogan, K., \& Hung, M.-W. (1999). Can the gains from international diversification be achieved without trading abroad? Journal of Finance, 54(6), 2075-2107.

Evans, J. L., \& Archer, S. H. (1968). Diversification and the reduction of dispersion: An empirical analysis. Journal of Finance, 23(5), 761-767.

Gee, C. S., \& Karim, M. Z. A. (2005). Stock price integration in the Malaysian stock market. Thammasat Economic Journal, 23(3), 123-145.

Goetzmann, W. N., \& Kumar, A. (2008). Equity portfolio diversification. Review of Finance, 12(3), 433-463.

Granger, C. W. J. (1981). Some properties of time series data and their use in econometric model specification. Journal of Econometrics, 16(1), 121-130.

Grubel, H. G., \& Fadner, K. (1971). The interdependence of international equity markets. Journal of Finance, 26(1), 89-94.

Husain, F., \& Saidi, R. (2000). The integration of the Pakistani equity market with international equity markets: An investigation. Journal of International Development, 12(2), 207-218.

Hussain, S. H., Sabir, H. M., Ali, Y., Ali, S. J., \& Ismail, A. (2013). Interdependence of South Asian and developed stock markets and their impact on KSE (Pakistan). Asian Economic and Financial Review, 3(1), 16-27. 
Iqbal, A., Khalid, N., \& Rafiq, S. (2011). Dynamic interrelationship among the stock markets of India, Pakistan and United States. International Journal of Economics and Management Engineering, 5(1), 8-14.

Khan, S. N., \& Aslam, M. S. (2014). Cointegration of Karachi Stock Exchange with major South Asian stock exchanges. International Journal of Accounting and Financial Reporting, 4(1), 106-117.

Levy, H., \& Marshall, S. (1970). International diversification of investment portfolios. American Economic Review, 60(4), 668-675.

Longin, F., \& Solnik, B. (1995). Is the correlation in international equity returns constant: 1960-1990? Journal of International Money and Finance, 14(1), 3-26.

Markowitz, H. (1952). Portfolio selection. Journal of Finance, 7(1), 77-91.

Masih, A. M. M., \& Masih, R. (2002). Propagative causal price transmission among international stock markets: Evidence from the pre- and post-globalization period. Global Finance Journal, 13(1), 63-91.

Mun, K.-C. (2005). Contagion and impulse response of international stock markets around the 9-11 terrorist attacks. Global Finance Journal, 16(1), 48-68.

Noor, M. A., Khan, M. M. A., \& Khan, M. A. (2014). Co-movement analysis among different sectors of Indian stock market. International Journal of Research, 1(4), 540-556.

Odier, P., \& Solnik, B. (1993). Lessons for international asset allocation. Financial Analysts Journal, 49(2), 63-77.

Sankaran, J. K., \& Patil, A. A. (1999). On the optimal selection of portfolios under limited diversification. Journal of Banking and Finance, 23(11), 1655-1666.

Schwebach, R. G., Olienyk, J. P., \& Zumwalt, J. K. (2002). The impact of financial crises on international diversification. Global Finance Journal, 13(2), 147-161. 
Wang, Z., Kutan A. M., \& Yang, J. (2005). Information flows within and across sectors in Chinese stock markets. Quarterly Review of Economics and Finance, 45(4-5), 767-780.

Wong, W. K., Penm, J., Terrell, R. D., \& Lim, K. Y. C. (2004). The relationship between stock markets of major developed countries and Asian emerging markets. Journal of Applied Mathematics and Decision Sciences, 8(4), 201-218.

World Bank. (1997). Private capital flows to developing countries: The road to financial integration. New York: Oxford University Press. 
Appendix

\section{List of selected companies in each sector}

\begin{tabular}{|c|c|c|}
\hline Automobiles and parts & Commercial banking & Cement \\
\hline $\begin{array}{l}\text { Honda Atlas Cars } \\
\text { (Pakistan) Ltd }\end{array}$ & Allied Bank Ltd & Bestway Cement Ltd \\
\hline Atlas Honda Ltd & National Bank of Pakistan & Fauji Cement Company Ltd \\
\hline $\begin{array}{l}\text { Pak Suzuki Motor } \\
\text { Company Ltd }\end{array}$ & United Bank Ltd & $\begin{array}{l}\text { Maple Leaf Cement Factory } \\
\text { Ltd }\end{array}$ \\
\hline Indus Motor Company Ltd & Habib Bank Ltd & $\begin{array}{l}\text { DG Khan Cement Company } \\
\text { Ltd }\end{array}$ \\
\hline Atlas Battery Ltd & MCB Bank Ltd & Lucky Cement Ltd \\
\hline Chemicals & Electricity & Foods \\
\hline $\begin{array}{l}\text { Fatima Fertilizer Company } \\
\text { Ltd }\end{array}$ & Hub Power Company Ltd & Engro Foods Ltd \\
\hline $\begin{array}{l}\text { Fauji Bin Qasim Fertilizers } \\
\text { Ltd }\end{array}$ & $\begin{array}{l}\text { Kot Addu Power Company } \\
\text { Ltd }\end{array}$ & National Foods Ltd \\
\hline $\begin{array}{l}\text { Fauji Fertilizer Company } \\
\text { Ltd }\end{array}$ & PAKGEN Power Ltd & Ismail Industries Ltd \\
\hline $\begin{array}{l}\text { Dawood Hercules } \\
\text { Corporation Ltd }\end{array}$ & Nishat Chunian Power Ltd & Nestle Pakistan Ltd \\
\hline Engro Corporation Ltd & Nishat Power Ltd & Rafhan Maize Products Ltd \\
\hline Oil and gas & Personal goods and textiles & Pharma and biotech \\
\hline $\begin{array}{l}\text { Oil and Gas Development } \\
\text { Company Ltd }\end{array}$ & Nishat Mills Ltd & $\begin{array}{l}\text { GlaxoSmithKline (Pakistan) } \\
\text { Ltd }\end{array}$ \\
\hline Pakistan Petroleum Ltd & Ibrahim Fibre Ltd & $\begin{array}{l}\text { Abbot Laboratories } \\
\text { (Pakistan) Ltd }\end{array}$ \\
\hline $\begin{array}{l}\text { Pakistan State Oil Company } \\
\text { Ltd }\end{array}$ & Kohinoor Textile Mills Ltd & Searle Company Limited \\
\hline Pakistan Oilfields Ltd & $\begin{array}{l}\text { Gul Ahmed Textile Mills } \\
\text { Ltd }\end{array}$ & IBL HealthCare Ltd \\
\hline $\begin{array}{l}\text { Mari Petroleum Company } \\
\text { Ltd }\end{array}$ & Nishat Chunian Ltd & Highnoon Laboratories Ltd \\
\hline \multicolumn{3}{|l|}{ Tobacco } \\
\hline $\begin{array}{l}\text { Pakistan Tobacco Company } \\
\text { Ltd }\end{array}$ & Philip Morris (Pakistan) Ltd & $\begin{array}{l}\text { Khyber Tobacco Company } \\
\text { Ltd }\end{array}$ \\
\hline
\end{tabular}

